\title{
NOTES
}

\section{Taxonomic Position of Additional Zymomonas mobilis Strains}

\author{
J. SWINGS, K. KERSTERS, AND J. DE LEY \\ Laboratory of Microbiology and Microbial Genetics, Faculty of Sciences, State University, \\ 9000 Ghent, Belgium
}

The strains CP3 and CP4, isolated from fermenting sugar-cane juice in Brazil, and the strain Ag11, isolated from fermenting agave juice in Mexico, belong in Zymomonas mobilis subsp. mobilis. The existence of a separate $Z$ ymomonas mobilis subsp. recifensis for the former two is not justified. The strains NCIB 8777 and NCIB 10565 from sick cider and apple pulp, respectively, in England, belong in Zymomonas mobilis subsp. pomaceae. Protein electropherograms allow a quick and accurate identification in Zymomonas.

In previous papers $(2,4,5,6)$ we examined the genotype and phenotype of the genus Zymomonas and concluded that the type and sole species Zymomonas mobilis consists of two subspecies mobilis and pomaceae.

We report here on the taxonomic position of five additional strains, received as $Z$. mobilis var. recifensis $\mathrm{CP} 3$ and $\mathrm{CP} 4, Z$. mobilis Ag11, and $Z$. anaerobia var. pomaceae NCIB 8777 and NCIB 10565. It is the purpose of the present communication to identify and name the above strains correctly and to locate them in our nomenclatural system (1). In previous papers $(2,5)$ we demonstrated that the taxonomy of Zymomonas, as described in Bergey's Manual of Determinative Bacteriology (1), is not satisfactory. The methods used have been described elsewhere $(2,4,6)$. The main phenotypic features and the protein electropherograms of each strain were determined and compared with known data $(2,6)$. Two type strains were included for comparison.

Correct taxonomic position of Zymomonas strains CP3 and CP4.Z. mobilis var. recifensis has been proposed as a new subspecies by Gonçalves de Lima et al. (3; personal communication) for the strains CP1, CP2, CP3, and CP4 isolated from fermenting sugar-cane juice in Recife, Brazil. These authors compared them to $Z$. mobilis strain Ag11 (see below). They differentiated $Z$. mobilis var. recifensis by: (i) a better growth yield, (ii) growth at $37^{\circ} \mathrm{C}$ and the ability of fermentation at $42^{\circ} \mathrm{C}$, (iii) greater aerotolerance; (iv) no $\mathrm{H}_{2} \mathrm{~S}$ formation, and (v) a characteristic antagonistic pattern towards 41 microorganisms. We found that both strains CP3 and CP4 were phenotypically identical (Table 1) and that their protein electrophero- grams were indistinguishable (Fig. 1). We conclude that both isolates are but subcultures of the same organism. We found no significant differences in growth yields between CP3 and CP4 and more than 40 other strains from our collection. Both strains still grew at $38^{\circ} \mathrm{C}$ but so did 28 other strains from the $Z$. mobilis subsp. mobilis (2). Both strains grew well aerobically, reaching a colony diameter of $3 \mathrm{~mm}$ after 7 days at $30^{\circ} \mathrm{C}$. The high aerotolerance was not restricted to these strains since, for example, the centrotype strain ATCC 29191 from $Z$. mobilis subsp. mobilis grew equally well aerobically. $\mathrm{H}_{2} \mathrm{~S}$ formation occurred rarely (and only in traces) in Zymomonas (2). The phenotypical diagnosis of $Z$. mobilis subsp. recifensis as given by Gonçalves de Lima et al. (3) is thus very equivocal and not subspecific. Furthermore, its protein electropherograms are very similar to these of $Z$. mobilis subsp. mobilis (6). For all of these reasons we conclude that the existence of $Z$. mobilis var. recifensis Gonçalves et al. is not justified and that it is but a subjective synonym of $Z$. mobilis subsp. mobilis De Ley and Swings 1976, 146.

Correct taxonomic position of Zymomonas strain Ag11. Zymomonas strain Ag11 was isolated from fermenting agave juice in Mexico (3). Its protein electropherogram indicated that it belongs in $Z$. mobilis subsp. mobilis. It was characterized by a strong $\mathrm{P}$ band at the bottom of the gel, resembling strain 1.1 (Fig. 1). Phenotypically, strain Ag11 differed from CP3 and CP4 and/or from the centrotype ATCC 29191 in a few features only, namely, pleomorphism, no fermentation of sucrose, formation of $\mathrm{H}_{2} \mathrm{~S}$, growth in standard medium $+0.0075 \% \mathrm{KCN}$, and no growth at $38^{\circ} \mathrm{C}$. These differences should 


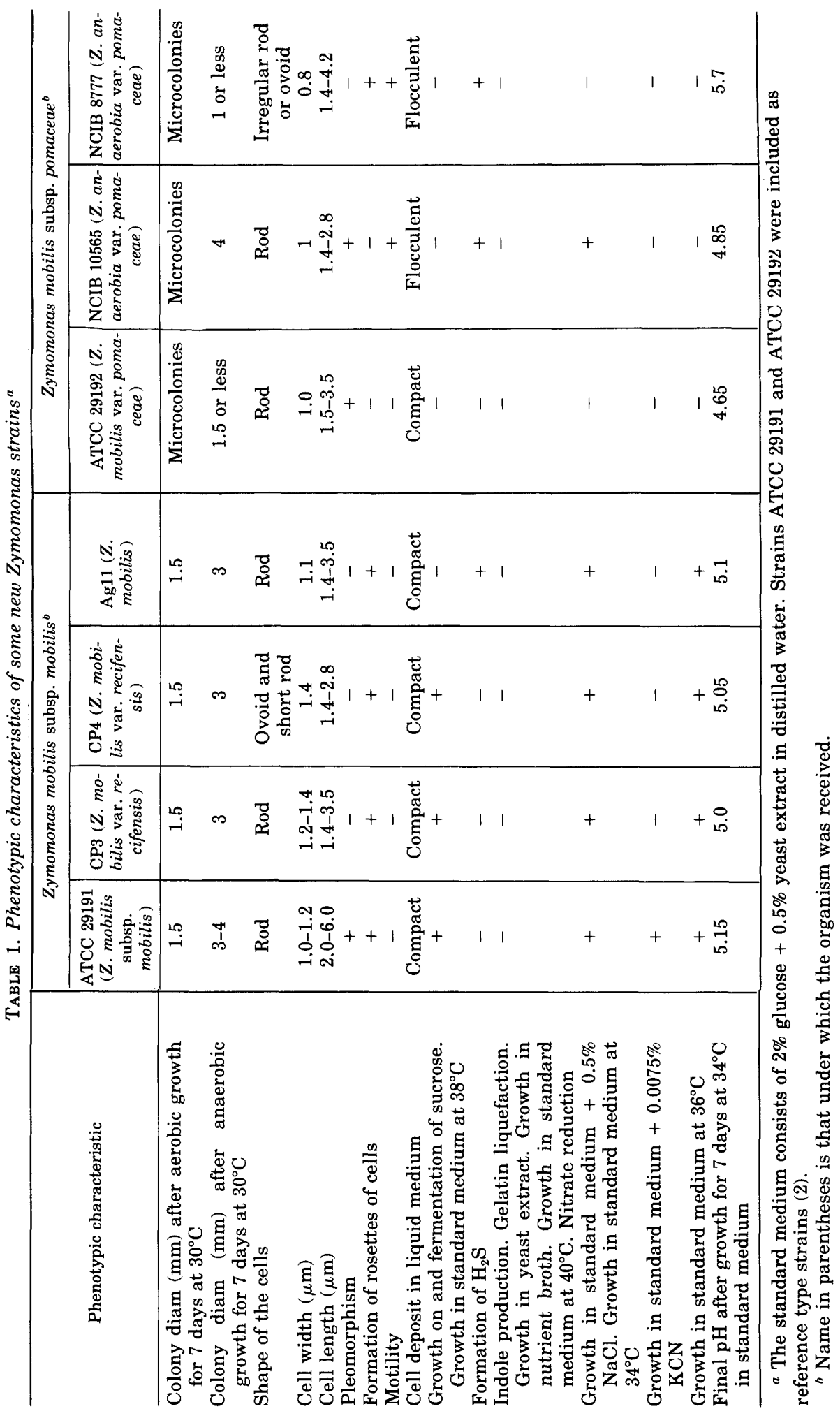




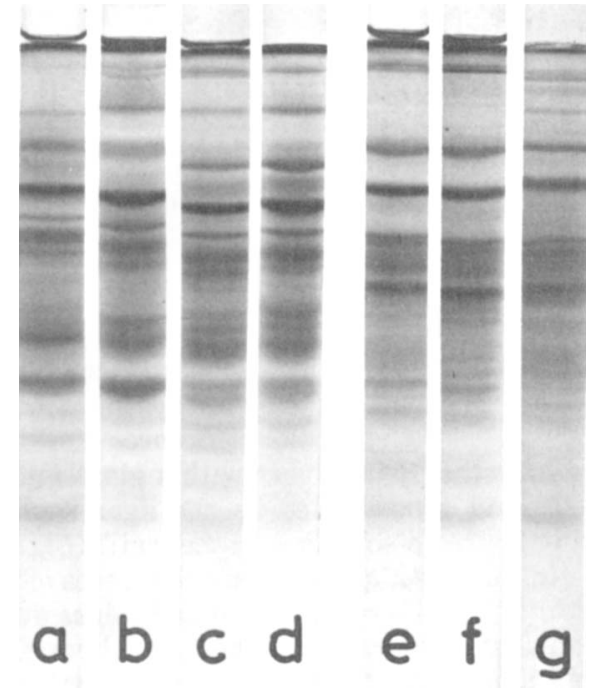

FIG. 1. Protein electropherograms of some new Zymomonas strains. From left to right: normalized protein patterns of the strains $Z$. mobilis subsp. mobilis 1.1 (a), Ag11 (b), CP3 (c), CP4 (d), and Z. mobilis subsp. pomaceae NCIB 10565 (e), NCIB 8777 (f), and ATCC 29192 (g). The strains 1.1 (a) and ATCC 29192 (g) were included as references. These results must be compared with Fig. 2 of Swings and De Ley (5).

be regarded as strain specific. We conclude that strain Ag11 belongs in Z. mobilis subsp. mobilis (2).

Correct taxonomic position of Zymomonas strains NCIB 8777 and NCIB 10565. Zymomonas strains NCIB 8777 and NCIB 10565 were both received as $Z$. anaerobia var. pomaceae. The former strain was isolated from "sick cider" and the latter was isolated from apple pulp in England. The protein patterns and phenotypic features of both strains were nearly identical with those of strain ATCC 29192 (Fig. 1, Table 1 ), the proposed type strain of $Z$. mobilis subsp. pomaceae (2). Phenotypically there are some minor differences between these strains (Table 1). Obviously these tests are only useful for strain differentiation and not for subspecies differentiation. Both strains NCIB 8777 and NCIB 10565 thus belong in $Z$. mobilis subsp. pomaceae together with strain ATCC 29192.

We thus conclude the following: (i) the correct taxonomic position of the five new $Z y m o-$ monas strains has been established; (ii) the existence of $Z$. mobilis subsp. recifensis is not justified; (iii) the most useful phenotypical test to differentiate between $Z$. mobilis subsp. pomaceae and $Z$. mobilis subsp. mobilis is the growth in $2 \%$ glucose $+0.5 \%$ yeast extract at $36^{\circ} \mathrm{C}$; and (iv) after a rapid tentative identification by a few characteristic phenotypical tests of a new specimen as $Z y$ momonas, the easiest way to achieve a prompt and accurate identification is by comparison of protein electropherograms.

\section{REPRINT REQUESTS}

Address reprint requests to: Prof. J. De Ley, Laboratory of Microbiology, R.U.G., Ledeganckstraat 35, B-9000 Gent, Belgium.

\section{LITERATURE CITED}

1. Carr, J. G. 1974. Genus Zymomonas Kluyver and van Niel 1936, p. 399. In R. E. Buchanan and N. E. Gibbons (ed.), Bergey's manual of determinative bacteriology, 8th ed. Williams \& Wilkins Co., Baltimore.

2. De Ley, J., and J. Swings. 1976. Phenotypic description, numerical analysis, and proposal for an improved taxonomy and nomenclature of the genus Zymomonas Kluyver and van Niel 1936. Int. J. Syst. Bacteriol. 26:146-157.

3. Gonçalves de Lima, O., J. M. De Araújo, I. E. Schumacher, and E. Cavalcanti Da Silva. 1970. Estudos de microrganismos antagonistas presentes nas bebidas fermentadas usadas pelo povo do Recife. I. Sôbre uma variedade de Zymomonas mobilis var. recifensis (Gonçalves de Lima, Araújo, Schumacher \& Cavalcanti) (1970), isolada de bebida popular denominada "caldo-de-cana-picado." Rev. Inst. Antibiot. Univ. Recife 10:3-15.

4. Swings, J., and J. De Ley. 1975. Genome deoxyribonucleic acid of the genus Zymomonas Kluyver and van Niel 1936: base composition, size, and similarities. Int. J. Syst. Bacteriol. 25:324-328.

5. Swings, J., and J. De Ley. 1977. The biology of Zymomonas. Bacteriol. Rev. 41:1-46.

6. Swings, J., K. Kersters, and J. De Ley. 1976. Numerical analysis of electrophoretic protein patterns of Zymomonas strains. J. Gen. Microbiol. 93:266-271. 